\title{
Volatilidade dos Fluxos Financeiros no Brasil: uma Análise Empírica por meio do Modelo ARCH (Modelo Autorregressivo com Heterocedasticidade Condicional)
}

\author{
Volatility of Financial Flows in Brazil: \\ an Empirical Analysis Through the ARCH Model \\ (Autorregressive Conditional Heteroskedastic Model)
}

\author{
Vanessa da Costa Val Munhoz ${ }^{1}$
}

Vanessa Petrelli Corrêa ${ }^{2}$

\begin{abstract}
Resumo: O objetivo deste trabalho é medir a volatilidade da conta financeira do Balanço de Pagamentos nacional, para mostrar que os fluxos de capitais de curto prazo direcionados ao Brasil são fortemente dominados por movimentos expectacionais, que geram efeitos macroeconômicos, como os impactos negativos sobre os juros domésticos, dívida pública e Risco-País. Argumenta-se que a volatilidade que caracterizou as contas financeiras a partir da implantação do Plano Real permanece mesmo após a flexibilização do câmbio. Para realizar esse intento, será utilizado um modelo econométrico específico para séries temporais, o modelo $\mathrm{ARCH}$ (modelo autorregressivo com heterocedasticidade condicional). Através da análise que conjuga as volatilidades médias anuais e a participação relativa de cada subconta na conta financeira de nível de hierarquia superior, o artigo conclui que as contas mais voláteis são justamente aquelas de maior caráter especulativo e viés de curto prazo.
\end{abstract}

Palavras-chave: Fluxos de capitais. Balanço de pagamentos brasileiro. Volatilidade.

Abstract: The aim of this paper is to measure the financial account volatility of the Brazilian Balance of Payments. We intend to show that the short run capital flows toward Brazil are strongly characterized by speculative movements, which generate macroeconomic effects, such as the negative impact on the domestic interest rate, the public debt and the country risk. The main argument here is that the volatility remains even after a flexible exchange rate regime. In order to accomplish this objective we will use a specific econometric model for time series, the ARCH model (autoregressive conditional heteroskedascity model). Through the analysis that links the annual volatility average and the relative

\footnotetext{
1 Professora do Instituto de Economia da UFU e Doutoranda em Economia pelo Cedeplar/UFMG. E-mail: vanessacostaval@ie.ufu.br

2 Professora do Instituto de Economia da UFU. E-mail: vanplli@ufu.br
} 
participation of each sub-account in the financial account of superior hierarchy, the paper concludes that the most volatile accounts are just that ones with most speculative and short term bias.

Keywords: Capital flows. Brazilian balance of payments. Volatility.

JEL Classification: F32; F37; G11; G15.

\section{1 lntrodução}

O ingresso de capitais com grande flexibilidade ${ }^{3}$ e perspectiva especulativa - resposta ao processo de "globalização financeira" - foi crescentemente incorporado ao Balanço de Pagamentos brasileiro, desde a abertura financeira que ocorreu a partir do início da década de 1990. Esses fluxos são fortemente voláteis e respondem rapidamente a mudanças na conjuntura internacional, em grande parte das vezes independentemente dos indicadores econômicos domésticos.

O arranjo macroeconômico desenhado desde a implantação do Plano Real, cujos pilares estiveram na abertura econômica e atração de capitais estrangeiros conjugados à centralidade da estabilização de preços, magnificou o volume do ingresso desse tipo de capitais. Por conseguinte, o país se tornou fortemente vulnerável à dinâmica dos ciclos financeiros internacionais e a efeitos contágio, conforme se pôde constatar pelas crises do México (1994-1995), da Ásia (1997) e da Rússia (1998).

Edwards (1998a; 1998b; 2001), estudando a volatilidade da taxa básica de juros e do Mercado de Capitais de vários países do Mercosul, constatou a existência de períodos de forte e alta volatilidade para essas variáveis durante a década de 1990. Esses estudos se concentraram especialmente em analisar as crises ocorridas na referida década e concluíram que os movimentos de picos de instabilidade estiveram relacionados às crises internacionais (Edwards, 2001, p. 2). Ademais, encontraram evidência de uma forte relação entre as dinâmicas dessas volatilidades nos diferentes países estudados.

No caso brasileiro, após o efeito das referidas crises, o país adotou o regime de taxas de câmbio flutuantes ${ }^{4}$ conjugado à implantação do Regime

3 Consideramos "fluxos de capitais flexíveis", aqueles que podem se reverter rapidamente a qualquer mudança de expectativas. Para os propósitos desse trabalho, são eles: os fluxos de Investimentos em Carteira; os fluxos de Moeda e Depósitos; os fluxos de Derivativos; e os fluxos relacionados a empréstimos (bancários) de curto prazo. Ainda que parte dos Investimentos classificados como Investimentos Diretos possam ser considerados nessa categoria por estarem relacionados à posse de ações que podem ser rapidamente transacionadas, esses não estão sendo considerados na classificação ora utilizada.

4 É sabido que de junho de 1994 a janeiro de 1999 vigorou no Brasil o sistema de bandas cambiais. 
de Metas de Inflação, definindo uma nova etapa da política macroeconômica em que o manejo de tal política passou a centrar-se no combate à inflação, pela via do movimento da taxa de juros. O nosso ponto é o de que essa política, articulada à manutenção da abertura financeira e à centralidade do combate à inflação, acabou por manter o país na armadilha dos juros altos e do baixo crescimento econômico, tendo em vista a permanência da forte dependência do país aos acontecimentos dos mercados financeiros internacionais.

Inserido nesse contexto, o objetivo deste trabalho é medir a volatilidade da conta financeira do Balanço de Pagamentos nacional, detectando os fluxos das subcontas que mais influenciam essa volatilidade total e tentando analisar se os fluxos de capitais mais flexíveis são aqueles fortemente dominados por movimentos expectacionais e especulativos, que se gestam nos mercados externos e que acabam gerando impactos sobre os juros domésticos, Dívida Pública e Risco-País.

Argumenta-se que a volatilidade que caracterizou as contas financeiras a partir da implantação do Plano Real permanece, mesmo após a flexibilização do câmbio; quando começam a se apresentar crescentes superávits comerciais no Balanço de Pagamentos brasileiro; e quando os indicadores de endividamento externo melhoram.

O intuito específico é analisar a instabilidade das séries do fluxo de capitais, indicando as subcontas financeiras mais voláteis nas duas fases a serem analisadas: fase 1 - 1995 a 1998; e fase 2-1999 a 2005. Para realizar esse intento, será utilizado um modelo econométrico específico para séries temporais, o modelo ARCH (modelo autorregressivo com heterocedasticidade condicional), que permite a modelagem da variância de contas financeiras.

Antes da realização do estudo empírico, realiza-se uma retrospectiva sobre a natureza e a dinâmica volátil dos fluxos internacionais de capitais direcionados aos países emergentes, em especial ao Brasil. Para tanto, dedicam-se duas seções. Na primeira seção do trabalho, discutiremos o movimento das contas externas durante o período de câmbio administrado e a montagem da armadilha macroeconômica. Em seguida, discutiremos os movimentos dos fluxos internacionais de capitais após a implantação do Regime de Metas de inflação e a permanência da volatilidade desses fluxos. Por sua vez, na terceira seção, encontrar-se-á a análise empírica e, por último, à guisa de conclusão, apresentaremos algumas considerações finais. 


\section{Movimento do Balanço de Pagamentos Brasileiro entre 1994 e 1998 e o Crescimento da Vulnerabilidade das Contas Externas}

A estratégia de estabilização de preços aventada pelo Plano Real, que teve início em julho de 1994, foi marcada pela adoção de reformas econômicas ${ }^{5}$ e de um novo padrão monetário, além da colocação em prática de uma política monetária calcada principalmente na âncora cambial (crawling peg). O Plano implantado teve sucesso, em parte, por conjugar uma política de forte controle da inflação com um rápido processo de abertura financeira (iniciado anteriormente e aprofundado durante o período 1994-1998) em uma época de grande liquidez internacional, sendo que a utilização do mecanismo de valorização do câmbio foi parte importante do ajuste implementado.

Seguimos a interpretação de que essa articulação de política econômica, que centrou o combate à inflação como o principal foco da política gerou, no entanto, importantes passivos, especialmente o relativo ao crescimento da vulnerabilidade externa; o vinculado à expansão da dívida pública; e, por fim, o baixo crescimento econômico que também pode ser considerado um passivo para o país.

Segundo esse argumento, o movimento de abertura, articulado aos juros altos em período de abundância de liquidez financeira, produziu um processo de valorização do câmbio - funcional à política de combate à inflação. Esse arranjo macroeconômico foi a principal causa dos referidos passivos (CORRÊA; ALMEIDA FILHO, 2003).

Nesse contexto, o aprofundamento da abertura financeira é visto como um dos pilares do crescimento da instabilidade (TAVARES; FIORI, 1997; GONÇALVES, 1996; PRATES, 1997; SICSÚ, 2006). A abertura externa foi uma resposta ao processo de "globalização financeira", que foi fortemente marcado pela liberalização dos movimentos de capitais e provocou uma elevação do fluxo de recursos para as economias emergentes. ${ }^{6}$ Cabe ressaltar que tal processo envolveu a liberalização especial-

5 Dentre as reformas implementadas nesse período podemos destacar as privatizações de empresas estatais, principalmente no setor de telecomunicações, química, estrada, bancos e mineração; a liberalização comercial e financeira, aprofundada através de tarifas às importações e da eliminação de barreiras não tarifárias; e a reestruturação do sistema financeiro. Essa última se destaca com a criação do PROER - Programa de Estímulo à Reestruturação e ao Fortalecimento do Sistema Financeiro - cujo objetivo era estimular e reestruturar o sistema financeiro nacional.

6 Aqui estamos tratando do ciclo financeiro de liquidez a partir da década de 1980. Deve-se destacar que esse ciclo diferenciou-se largamente do ciclo anterior da década de 1970, durante o qual os fluxos de capitais para os países emergentes tinham a forma predominante de empréstimos sindicalizados, ciclos menos recorrentes e menor número e heterogeneidade dos agentes envolvidos. Cabe apontar ainda que no final da década de 1970 seguiu-se uma 
mente dos fluxos de recursos de Investimentos em Carteira de brasileiros e estrangeiros, recursos esses que apresentam alto potencial de reversão. ${ }^{7}$

No início da década de 1990, foi observado um momento de fartura de capitais externos, tendo sido observado um direcionamento de capitais privados dos países centrais para a América Latina em busca de maior rentabilidade, ${ }^{8}$ visto que se apresentava um movimento de queda nas taxas de juros norte-americanas. Parte importante desses capitais vinculava-se a fluxos relacionados aos Investimentos em Carteira e à Moeda e Depósitos do Balanço de Pagamentos, que possuem um viés mais especulativo, sendo que estão continuamente buscando alta lucratividade e possibilidade de ganhos de arbitragem. Ademais, nesse período, foram efetuados elevados volumes de Investimentos Diretos Estrangeiros, que estavam envolvidos nos processos de privatizações das empresas públicas e seguiu-se também um fluxo de recursos que ingressaram pela via de empréstimos bancários (na conta Outros Investimentos).

$\mathrm{Na}$ medida em que o ciclo de liquidez permanecia por um longo período, paulatinamente foi-se reduzindo a cautela das aplicações internacionais, assim como dos tomadores de empréstimos das economias emergentes, resultando no crescimento da especulação entre os ativos e operações mais alavancadas, e numa consequente bolha especulativa nos ativos das economias emergentes.

O primeiro sinal de perigo surgiu em dezembro de 1994, com a crise do México, sendo que as repercussões dessa crise (o "efeito Tequila") provocaram uma mudança no cenário em que se processava o ajuste das economias latino-americanas, ao elevar o risco cambial dos investimentos. Os investidores, movidos pelas finanças de mercado, passaram a vender seus ativos dos países latino-americanos, retirando grandes volumes de capitais do conjunto dessas economias emergentes. Ou seja, reagiram rapidamente diante de um fato, aparentemente localizado, o que passou a se tornar um traço característico das reversões dos ciclos de liquidez no contexto da globalização financeira (PRATES; FARHI, 2004).

forte retração das fontes de financiamento externo voluntário e, com isso, gerou-se uma crise da dívida externa que afetou, principalmente, os países da América Latina.

7 Em nosso texto, usaremos o conceito de capitais flexíveis e não de "fluxos de curto prazo". Isso porque, mesmo os fluxos relacionados a aplicações em Títulos de Renda Fixa de longo prazo, por exemplo, têm alto potencial de reversão, pois podem ser vendidos em mercados secundários.

Cabe indicar, no entanto, que os capitais que buscam títulos mais arriscados são apenas uma pequena parte do capital em geral, que se concentra em títulos considerados mais estáveis. Lopes-Mejía (1999) indicam que em 1999, 140 dos 166 países em desenvolvimento contavam com menos de $5 \%$ dos influxos totais de capitais. 


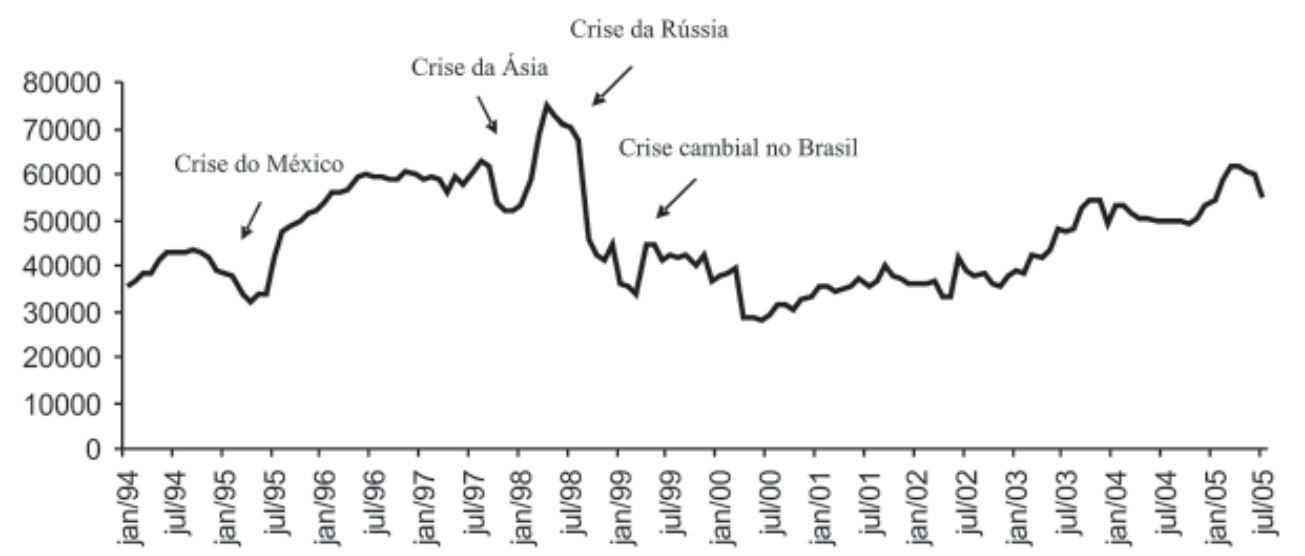

Gráfico 1 - Reservas internacionais - Conceito liquidez - Total (US\$ milhões)

Fonte: Elaboração própria a partir de dados do Banco Central do Brasil.

Conforme vemos no Gráfico 1, o Brasil sofreu diretamente o impacto da crise mexicana, com uma queda brusca nas reservas internacionais em meados do ano de 1995. Esse ataque foi resultante do referido "efeito contágio" dessa crise, que atingiu as economias do sudeste asiático e também da América Latina. Ressalte-se que o impacto da crise do México teve curta duração no Brasil e em outros países emergentes, sendo que a mesma não significou, efetivamente, uma redução maior do movimento de liquidez internacional, que continuaria se processando. Ainda assim, pode-se dizer que essa crise marcou o "início do fim" da fase de alta liquidez para as economias emergentes; período esse que se encerra com a crise da Rússia. Depois dela, os mercados financeiros entraram numa fase de redução de liquidez, intervalo que abarca a deflagração da crise do Brasil (1999).

No caso do Brasil, podemos considerar que na fase de liquidez (início da década de 1990-1996) iniciou-se o processo de montagem de uma "armadilha macroeconômica" (TAVARES, 1998), com uma elevação de passivos, a saber: o aumento do endividamento externo e da fragilização do Balanço de Pagamentos; o aumento da Dívida Pública como resultado da política de compra do excesso de reservas internacionais e dos juros altos; e a queda do crescimento econômico (CORREAA; ALMEIDA FILHO, 2003).

No que se refere ao passivo sobre as contas externas, a liberalização comercial e financeira, em conjunto com a sobrevalorização da moeda nacional (provocada pela maciça entrada de capitais externos) gerou uma elevação considerável das importações, concomitantemente ao lento crescimento das exportações e, por conseguinte, gerou o crescimento do déficit da Balança Comercial. Em paralelo, observou-se um crescente déficit da Conta de Serviços que, somado aos déficits da Balança Comercial, provocaram crescentes resultados negativos em Transações Correntes. 
Essa conta do Balanço de Pagamentos, que apresentava um resultado de U\$ 676 milhões em 1993 pulou para um valor de U\$ 33.416 milhões em 1998 (Tabela 1).

Esta situação não foi, à época, vista como problemática pelos gestores da Política Macroeconômica, pois a geração de recursos para cobrir os déficits em Transações Correntes se deu pela via da Conta Capital. O ingresso desses capitais voluntários foi garantido pela abertura financeira, aliada à adoção de elevadas taxas de juros, num momento de ampla liquidez dos mercados financeiros internacionais. Ademais, o programa de privatização atraiu posteriormente Investimentos Estrangeiros Diretos, conforme já apontado.

Tabela 1 - Sumário do Balanço de Pagamentos - 1994 a 2005 (US\$ milhões)

\begin{tabular}{c|c|c|c|c|c|c|c|c|c|c|c|c}
\hline D & 1994 & 1995 & 1996 & 1997 & 1998 & 1999 & 2000 & 2001 & 2002 & 2003 & 2004 & 2005 \\
\hline T.C. & -1811 & -18384 & -23502 & -30452 & -33416 & -25335 & -24225 & -23215 & -7637 & 4177 & 11738 & 13985 \\
\hline B.C. & 10466 & -3466 & -5599 & -6753 & -6575 & -1199 & -698 & 2651 & 13121 & 24794 & 33666 & 44073 \\
\hline S & -14692 & -18541 & -20350 & -25522 & -28299 & -6977 & -7162 & -7759 & -4957 & -4931 & -4677 & -8309 \\
\hline T.U. & 2414 & 3622 & 2446 & 1823 & 1458 & 1689 & 1521 & 1637 & 2390 & 2867 & 3268 & 3558 \\
\hline C.F. & 8692 & 29095 & 33968 & 25800 & 29702 & 17319 & 19326 & 27052 & 8005 & 5111 & -7356 & -9464 \\
\hline E.O. & 334 & 2207 & -1800 & -3255 & -4256 & 194 & 2637 & -531 & -66 & -793 & -2138 & -201 \\
\hline R.BP & 7215 & 12919 & 8666 & -7907 & -7970 & -7822 & -2262 & 3307 & 302 & 8496 & 2244 & 4320 \\
\hline
\end{tabular}

*D = Discriminação; T.C. $=$ Transações Correntes; B.C. $=$ Balança Comercial; $S=$ Serviços; T.U. $=$ Transações Unilaterais; C.F. $=$ Capital e Financiamento;

E.O. = Erros e Omissões; R.BP $=$ Resultado Balanço de Pagamentos.

Fonte: Banco Central do Brasil.

À medida que o nível dos juros altos internos atraía expressivo montante de capitais pela conta Investimentos em Carteira e Outros investimentos, geravam-se ingressos muito superiores aos necessários ao fechamento do Balanço de Pagamentos. Já que esses capitais engendram remunerações de juros e remessas de lucros ao exterior, necessariamente provocam-se também impactos crescentes sobre a conta Serviços, piorando o resultado de Transações Correntes. Ou seja, a dinâmica que conjugou liquidez inter- 
nacional, abertura financeira, moeda fraca, juros altos e sobrevalorização do câmbio gerou um resultado de Transações Correntes crescentemente negativo, exigindo-se recursos externos para o fechamento do Balanço de Pagamentos.

Essa exigência denota a fragilidade da economia brasileira frente aos acontecimentos internacionais, especialmente quando se observa que grande parte dos ingressos se vincula a recursos com alto potencial de volatilidade. De fato, desde o retorno dos fluxos de capitais, a partir de 1991, houve uma mudança importante da dinâmica da Conta Capital do Balanço de Pagamentos brasileiro. A forma atual dos fluxos financeiros internacionais relaciona-se fortemente com os investimentos de portfólio, que podem ser transacionados em mercados secundários, têm maior liquidez e, por isso, têm maior potencial de reversão frente a mudanças de expectativas. ${ }^{9}$

Paralela a essa piora progressiva das necessidades de recursos para o fechamento do Balanço de Pagamentos, a vulnerabilidade se faz sentir nos momentos de redução de recursos, resultante dos movimentos de contágio provocados por fatores externos ao país. O impacto desses acontecimentos e a verificação de que os movimentos de volatilidade se dão de forma casada em diferentes países periféricos deixa claro o fato de que retransmite-se ao conjunto da economia do país a volatilidade engendrada nos mercados financeiros internacionais.

Assim, é a dinâmica do mercado financeiro internacional que determina a característica dos fluxos de capitais para a periferia, ao passo que a dinâmica nos países centrais determina o volume dos fluxos (PRATES, 2005). Aqui merece destaque o argumento de que a intensificação do processo de globalização financeira atribuiu um valor exorbitante ao mercado e à especulação, gerando uma grande instabilidade nas relações monetárias e financeiras internacionais. Consequentemente, a economia internacional e as economias nacionais foram lançadas em um ambiente muito mais instável, ficando em posição muito mais vulneráveis. (AMADO, 2004; PLIHON, 1995). Ou seja, é a instabilidade das relações monetárias e financeiras internacionais que gera a vulnerabilidade externa nos países periféricos, incluindo o Brasil.

Como vemos no Gráfico 2, há rápida reversão de recursos, especialmente nas crises do México (1995), da Ásia (1997) e da Rússia (1998); em 1999, na crise brasileira que engendra a mudança cambial; em 2002, quando se conjuga um período de retração dos fluxos internacionais com condicionantes internos; no início de 2004, quando se apresenta a possibilidade de aumento mais rápido nas taxas de juros norte-americanas.

9 Para análise detalhada dos fluxos de capitais e suas composições nos anos 1990, vide Prates (1997). 
Por um lado, fica explícito o potencial de volatilidade dos fluxos financeiros e, de outro, é possível perceber que a dinâmica desses capitais pode estar vinculada a movimentos que não são definidos pela política econômica nacional. O nosso ponto é o de que, no caso do Brasil, o mix de política macroeconômica adotado pelas Autoridades Monetárias gerou passivos expressivos justamente nos momentos de extrema liquidez, que são difíceis de serem desmontados posteriormente.

No que cerne à composição dos recursos da Conta Financeira, observa-se que até 1996 ocorreu um expressivo ingresso pela conta Outros Investimentos e pela conta de Capitais em Carteira. No caso da conta Outros Investimentos, observa-se um forte peso dos fluxos de Moeda e Depósitos, de forma que a Conta Financeira passa a ser dominada por capitais altamente voláteis, que se movem fortemente determinados por elementos de expectativas. A partir de 1997, verificamos que as contas de Investimentos em Carteira e Outros Investimentos passaram a apresentar valores negativos. Com isso, embora tenha ocorrido um aumento do ingresso de capitais via Investimento Direto Líquido, a queda dos recursos das outras contas referidas fez com que o resultado da Conta Financeira ficasse aquém do déficit registrado em Transações Correntes entre 1997 e 2000, período em que se perdem reservas rapidamente (ver Tabela 1).

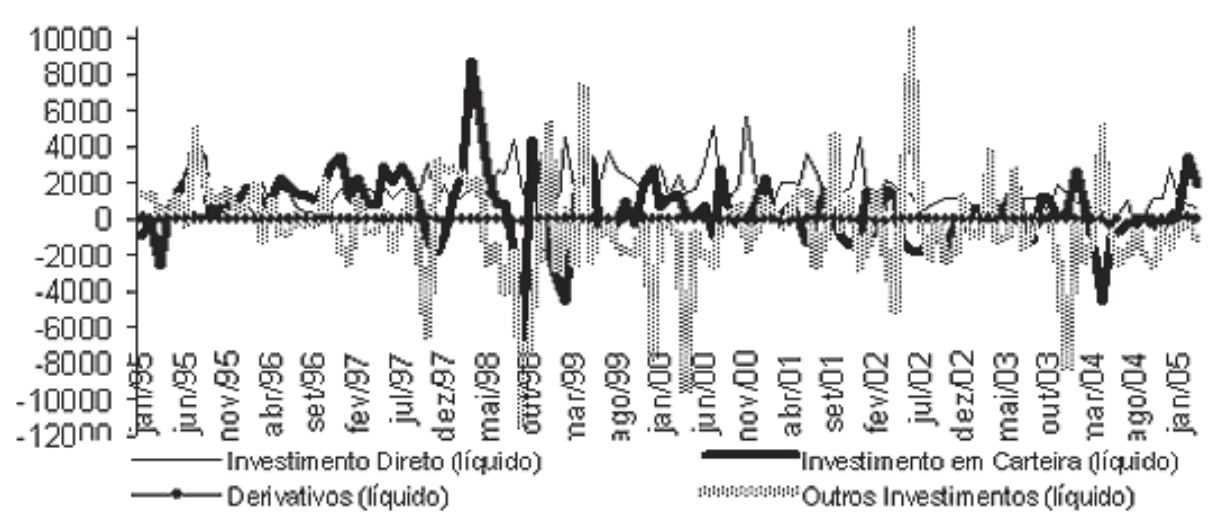

Gráfico 2 - Conta financeira - Dados mensais (U\$ Milhões)

Fonte: Banco Central do Brasil - elaboração própria.

Deve-se salientar ainda que a abertura financeira gera não apenas a mudança do perfil dos fluxos ${ }^{10}$ mas também uma elevação rápida dos mesmos. Nesse contexto, o ponto que queremos destacar é o de que as contas externas do país vão agregando continuamente capitais voláteis e que a dinâmica dos juros internos acaba ficando, em parte, subordinada à lógica de atração desses capitais. De fato, em situação de abertura

10 Ffrench-Davis (2003) aponta que os ciclos dos anos 1970 e dos anos 1980 se diferenciam pela sua composição. Tem havido um deslocamento do crédito de longo prazo para fluxos em carteira, de financiamento de curto e médio prazo. 
financeira, o movimento das Autoridades Monetárias de um país periférico no sentido de atrair explicitamente o capital especulativo quando o câmbio é administrado, envolve o oferecimento de juros capazes de gerar a rentabilidade mínima requerida por esses capitais, que é medida pelo Risco-País e acrescida do forward premium, que trata-se do risco cambial, que é medido no mercado futuro de câmbio. ${ }^{11}$

$\mathrm{Na}$ verdade, essa exigência de rentabilidade se faz sentir especialmente nos momentos de crise internacional. Nessa situação há um efeito contágio, que afeta o mercado futuro de câmbio (indicação de expectativa de desvalorização). Paralelamente, ocorre também uma fuga dos papéis brasileiros negociados no exterior, provocando uma queda no preço desses papéis e o consequente aumento do Risco-País. De forma correlata, os capitais dirigidos ao país se retraem rapidamente, provocando uma forte reversão na Conta Financeira.

Cabe ressaltar que a queda dos movimentos de capitais nessa primeira fase (1994-1998) se dá justamente quando as necessidades de recursos para o fechamento do Balanço de Pagamentos exigem forte ingresso de capitais, o que leva a que a Autoridade Monetária doméstica ajuste os juros básicos para cima, seguindo o aumento do forward premium e do Risco País. Então, para países periféricos, sem moeda forte e com forte peso de capitais voláteis em sua Conta Financeira, esses mecanismos de atração são essenciais para o ingresso de recursos mais voláteis, que estão continuamente em busca de alta rentabilidade e querem preservar sua capacidade de movimentar-se a qualquer momento.

Além da questão dos juros domésticos, a dinâmica macroeconômica montada afeta também a Dívida Pública. Na fase de liquidez, o excesso de ingresso de recursos ocorrido pelo forte afluxo dos capitais em busca de alta rentabilidade gerou um movimento de compra de reservas por parte da Autoridade Monetária, que foi possível pela via do aumento da Dívida Mobiliária Interna, sendo que o nível dos juros, por outro lado, também gerava impacto. Ademais, nas fases de retração de recursos, a instabilidade gerava a exigência de títulos pós-fixados à Selic e ao câmbio, levando a que as contas públicas sofressem diretamente com a instabilidade dessas duas variáveis.

11 Na verdade, o risco cambial envolve a somatória da expectativa de depreciação cambial mais o prêmio de risco de câmbio. O forward premium pode ser medido no mercado futuro de câmbio, sendo que Garcia e Olivares (1999) e Garcia e Didier (2001) usam um artigo clássico de Eugene Fama (1984) para a medição conjunta da variação do prêmio de risco e do componente esperado das taxas a termo. 


\section{Os Movimentos dos Fluxos Internacionais de Capitais após 1999: a Permanência da Volatilidade e da Vulnerabilidade}

Conforme já indicamos, a abundância de liquidez que marcou o ciclo pronunciado da década de 1990 teve seu fim a partir das crises que afetaram o sudeste asiático. Essas crises, já citadas anteriormente, foram seguidas da moratória da Rússia (1998), da crise cambial do Brasil (1999) e das crises da Turquia e da Argentina (2001-2002). Além disso, deve ser destacado que a retração dos fluxos de capitais para os países em desenvolvimento foi acentuada pelo desinflar da bolha especulativa nas Bolsas de valores americanas, pelos ataques de 11 de setembro e pela revelação de escândalos contábeis em corporações americanas de capital aberto (PRATES; FARHI, 2004).

Entre 1999 e 2002 os mercados financeiros internacionais passam a se caracterizar por uma dinâmica de feast or famine, o que quer dizer que se alternam momentos de abundância e escassez. (IMF, 2003; PRATES, 2005). Nesse sentido, podemos construir uma periodização a respeito dos movimentos dos fluxos internacionais de capital. Primeiramente, já comentamos que a crise da Rússia pôs fim ao período de feast do ciclo de liquidez dos anos 1990 e aí entra-se em uma fase de famine. Comentamos que nessa fase observou-se, no Brasil, uma acentuada fuga de capitais e, consequentemente, uma forte perda de reservas internacionais. O resultado foi o abandono do regime de câmbio administrado e a adoção do regime de câmbio flutuante, em janeiro de 1999. Cabe ressaltar que nessa fase se processa uma mudança no peso dos fluxos componentes do Balanço de Pagamentos. Houve uma redução dos Investimentos em Carteira, passando a se destacar um aumento do peso dos Investimentos Diretos Estrangeiros na Conta Financeira. ${ }^{12}$

Entre meados de 1999 e durante o ano 2000, observa-se uma fase de liquidez, ocorrendo a volta de recursos. Ainda assim, a conta Investimentos em Carteira mantém-se em patamares mais baixos, destacando-se a continuidade da entrada do Investimento Direto Estrangeiro. Ademais, observou-se uma redução dos ingressos de empréstimos e a queda da participação das contas de Moeda e Depósitos (de brasileiros e de estrangeiros) no Balanço de Pagamentos.

No entanto, este momento de liquidez foi de curta duração e a ele se alternaram períodos de fechamento do acesso dos papéis de países

12 Essa entrada de Investimento Estrangeiro Direto esteve associada, tanto ao avanço do processo de desestatização nos setores de utilidade pública (com destaque para o de telecomunicações), quanto à onda global de expansão das grandes corporações produtivas e financeiras, impulsionada pelas operações de fusão e aquisição e pelo longo período de crescimento econômico dos Estados Unidos (1992-2000) (CINTRA; PRATES, 2005). 
emergentes ao mercado financeiro internacional, com novos momentos de liquidez. No que tange aos mercados de títulos de dívida (Investimentos em Carteira), destaca-se que a retração desses recursos aos países periféricos permanece até 2002, passando a existir uma hierarquização entre tais países no que se refere ao direcionamento de recursos. Observa-se que os países da América Latina passam a serem menos procurados que os países do sudeste asiático e os da Europa oriental (PRATES; FARHI, 2004).

Os ataques de 11 de setembro de 2001 e as crises contábeis nos Estados Unidos geraram um período de forte escassez de recursos entre maio e novembro de 2002, verificando-se que, a partir de dezembro do mesmo ano, se engendra um novo ciclo de elevada liquidez para as economias emergentes, que voltam a receber grandes volumes de capital externo.

Salientamos que entre 1998 e 2002 - período relativo à ocorrência de feast or famine - os movimentos de volatilidade nos países periféricos estiveram associados à gestão da política monetária dos Estados Unidos, ou a fatos ocorridos nos países centrais que geraram reversão de expectativas. No caso da política monetária dos EUA, sua importância se explica pela centralidade do dólar enquanto moeda de pagamento internacional. Toda vez em que há um aumento (ou expectativa de aumento) mais expressivo da taxa de juros norte-americana, se processa um movimento de "fuga para a qualidade", sendo que os detentores de papéis vendem seus ativos em "moeda fraca" e se dirigem aos títulos americanos - que são considerados menos arriscados. Assim, as moedas não-conversíveis dos países emergentes são o primeiro alvo dos movimentos de fuga, indicando a vulnerabilidade desses países.

A partir do final de 2002 assiste-se um ciclo prolongado de liquidez que persiste até 2005 - ano em que o presente trabalho encerra sua análise. Aqui, cabe destacar que esse novo ciclo surgiu depois das reduções das taxas de juros norte-americanas, mostrando que a dinâmica da expansão ou retração de liquidez continua fortemente influenciada pelo movimento das taxas de juros norte-americanas. Além das baixas taxas de juros nos países centrais, Cintra e Prates (2005) colocam que as expectativas de retomada do crescimento econômico mundial e as intervenções dos bancos centrais asiáticos, sob a liderança do Banco do Japão, alimentaram esse novo ciclo de abundância de recursos, que se caracterizou a partir de dezembro do ano 2002.

Esse novo ciclo de liquidez mais duradouro difere do primeiro em alguns sentidos. De um lado, observa-se desde 1999 uma contração dos créditos bancários, que permanece relativamente, mesmo após 2002. De outro lado, a diferença é a de que no caso dos Investimentos em Carteira, depois de 2002, ocorre uma volta mais expressiva dos mesmos (Créditos) para os países emergentes. Mas, mesmo assim, seus volumes são menores 
do que os observados durante a década de 1990. Outro fenômeno referente aos Investimentos em Carteira dos Balanços de Pagamentos dos países periféricos é o de que os fluxos líquidos dos mesmos apresentam valores muito baixos, mesmo nesse novo período de liquidez. Isso se dá por que ocorrem movimentos de pagamentos e recompra de dívidas (GRIFFITHJONES, 2003) - fato que ocorre também no Brasil.

Considerando essa nova dinâmica, o ano de 2003 foi marcado por uma expansão das aplicações em títulos de dívida de países emergentes, o que foi influenciado pelas baixas taxas de juros dos países centrais (especialmente dos Estados Unidos), conjugadas com a expectativa dos investidores de uma melhora na economia mundial. Houve um forte aumento do "apetite pelo risco" e novas ondas de endividamentos mais arriscados passam a ocorrer (FARHI, 2004). Note-se, no entanto, que, ainda que se possa dizer que a partir do final de 2002 se inicia um ciclo de liquidez mais longo, no início dessa fase os mercados ainda estão fortemente cautelosos, o que, a nosso juízo, explica os impactos negativos sofridos pelo Brasil na chamada "crise das eleições".

Ademais, a existência de liquidez não indica que não haja movimentos de reversão de recursos. É o que ocorre, por exemplo, em 2004. No início daquele ano, a sinalização de que as taxas de juros norte-americanas iriam subir provocou uma instabilidade no mercado de títulos de dívida dos países emergentes, em particular dos títulos latino-americanos. Isso significou que os especuladores foram levados a reestruturar suas carteiras ao menor sinal de risco, gerando um movimento de volatilidade, ainda que não se possa considerar que tenha havido uma retração mais abrupta de liquidez (IMF, 2004).

Ou seja, mesmo considerando que houve: uma melhora nos indicadores de risco dos países periféricos; que os mesmos efetuaram ajustes macroeconômicos importantes; que os indicadores de vulnerabilidade melhoraram, o que se observa é que permanece um forte potencial de volatilidade nas contas financeiras dos Balanços de Pagamentos desses países, na medida em que essas continuam tendo um forte peso de capitais flexíveis. É isso que queremos comprovar com a análise empírica aqui proposta.

Portanto, grande parte dos fluxos de capitais direcionados aos países emergentes é influenciada por uma dinâmica exógena a esses países, visto que estão subordinados à lógica especulativa dos capitais, isso é, à realização de ganhos de capital em função da expectativa de variação do valor de mercado dos preços dos ativos no curto prazo (CINTRA; PRATES, 2005).

Nesse contexto, indicamos que as determinações relativas à escassez/ abundância de liquidez internacional de recursos para os países emergentes não estão relacionadas meramente aos indicadores de vulnerabilidade 
macroeconômica dessas economias, mas sim à dinâmica específica da política monetária dos países centrais e ao perfil e "apetite" dos investidores. Desse modo, a volatilidade inerente aos fluxos de capitais mais flexíveis afeta, sobremaneira, os países emergentes, como é caso do Brasil - especialmente se é alto o peso desses capitais no Balanço de pagamentos. Por isso, se justifica o estudo aqui proposto, qual seja, o de analisar a instabilidade dos fluxos de capitais, detectando quais são as subcontas financeiras mais voláteis. A hipótese subjacente é a de que as contas financeiras mais voláteis são as de caráter mais especulativo e com viés de curto prazo.

\section{Análise Empírica}

\subsection{Tratamento dos dados e recorte temporal}

Os dados dos movimentos de capitais do Brasil fazem parte do Sistema de Contas Nacionais, particularmente da Conta Financeira, que foi aberta para capturar fluxos que mais influenciam a volatilidade dessa conta. Tais dados constituem-se em séries temporais e envolvem recursos medidos em milhões de US\$, sendo a fonte o Banco Central do Brasil.

A Conta Financeira registra fluxos decorrentes de transações com ativos e passivos financeiros entre residentes e não-residentes. Basicamente, tal conta é dividida em quatro grupos: 1) Investimento Direto; 2) Investimentos em Carteira; 3) Derivativos; e 4) Outros Investimentos. Cada um desses grupos é desdobrado em demais subcontas para evidenciar detalhes específicos de cada conta. Por exemplo, o grupo de Investimentos Diretos é dividido em Investimento Direto no Exterior e Investimento Direto no País. Por sua vez, o Investimento Direto no Exterior é subdividido em duas modalidades, e assim por diante. Abrindo as contas em até cinco níveis de hierarquia, as contas financeiras totalizaram em 50 séries.

Como veremos a seguir, os grupos que apresentaram maior volatilidade durante o período analisado foram os Investimentos em Carteira e os Outros Investimentos. Dessa feita, a caracterização das contas financeiras aqui seguirá um maior rigor para estas subcontas, ${ }^{13}$ ao passo que apontaremos de maneira geral as demais subcontas.

Os Investimentos Diretos são divididos em Investimento Direto no Exterior e Investimento Direto no País, que por sua vez se subdividem em "participação no capital" e "empréstimos inter-companhias". O grupo Investimento em Carteira registra fluxos de ativos e passivos constituídos pela emissão de títulos de crédito, comumente negociados em mercados

13 Para explicação detalhada das subcontas da conta financeira do balanço de pagamentos vide Notas Metodológicas do Balanço de Pagamentos, das Notas Técnicas do Banco Central do Brasil, número 1 , de junho de 2001. 
secundários de papéis. São divididos em Investimentos em Carteira de Estrangeiros e de Brasileiros. Cada uma dessas subcontas também é dividida em: "aplicações em títulos de Renda Fixa" e "aplicações em companhias". Ainda citamos os títulos de renda fixa, classificados como "negociados no exterior" ou "negociados no país", o que também ocorre com as aplicações em companhias. Dentre os fluxos componentes dos Investimentos em Carteira, veremos que o que mais influencia a volatilidade dessa conta são os relativos a Investimentos de Estrangeiros em Carteira relacionados com títulos de dívida "negociados no exterior", que referem-se às captações brasileiras nas modalidades de bônus, notes e commercial papers lançados em mercados de capitais fora do país.

A conta Derivativos registra os fluxos financeiros relativos à liquidação de haveres e obrigações decorrentes de operações de swap, opções e futuros e os fluxos relativos aos prêmios de opções. Não inclui os fluxos de depósitos de margens de garantia vinculados às operações em bolsas de futuros, alocados em outros ativos e passivos de curto prazo.

Por fim, a conta Outros Investimentos é dividida em Outros Investimentos Brasileiros e Outros Investimentos Estrangeiros. Além da conta empréstimos (às autoridades Monetárias e a Outros setores), essa conta também contabiliza os chamados fluxos de "moeda e depósitos". A conta Moeda e Depósitos de Brasileiros contabiliza a movimentação de depósitos mantidos no exterior na forma de disponibilidades, cauções, depósitos judiciais e, ainda, as garantias para os empréstimos vinculados a exportações. Inclui a variação dos depósitos no exterior dos bancos comerciais e os depósitos relativos ao excesso de posição comprada dos bancos residentes depositados no Banco Central. Estão incluídas também as movimentações de garantias colaterais, na modalidade de depósitos, constituídas no âmbito do acordo de renegociação da dívida externa (Plano Brady). No caso da conta "moeda e depósitos de estrangeiros", estão contabilizadas as disponibilidades de não-residentes depositadas no país, incluindo a variação do saldo das contas de não-residentes abertas em amparo da Circular $n^{\circ}$ 2.677 de 10-04-1996 (antiga conta CC5).

A periodicidade dos dados é mensal, sendo que o recorte temporal, para análise dos resultados do modelo, compreende dois períodos, a saber: o primeiro se inicia em janeiro de 1995 e vai até dezembro 1998, e o segundo vai de janeiro de 1999 a março de 2005. A escolha dos períodos é justificada pela opção de se trabalhar em um momento após o controle da dinâmica inflacionária. ${ }^{14}$ No entanto, optou-se por dividir os períodos em dois, uma vez que no primeiro período o Brasil era marcado por taxas

14 A inflação anual que se situou num patamar médio de 483\% a.a., entre 1980 e 1993, foi reduzida a níveis de um dígito, em menos de três anos, após a implantação do Plano Real, em julho de 1994.

MUNHOZ, V. C. V.; CORRÊA, V. P. Volatilidade dos fluxos financeiros no Brasil: uma análise empírica... 
de câmbio fixas, ao passo que no segundo momento o câmbio passou a flutuar, conforme vimos em seções anteriores.

\subsection{Volatilidades das séries da conta financeira}

Esta seção se dedica ao exame da condição de volatilidade das séries temporais estudadas. Algumas estatísticas descritivas são utilizadas, frequentemente, por diversos estudos para retratar a volatilidade de séries temporais, como o desvio padrão, o coeficiente de variação, ou até mesmo a variância. No entanto, esses indicadores sofrem da limitação de não avaliar a volatilidade instantânea das séries. Para resolver esse problema, optou-se aqui pelo estudo de métodos da classe ARCH na análise da instabilidade das séries do fluxo de capitais.

\subsubsection{Modelo ARCH: especificação e procedimentos}

O modelo autorregressivo com heterocedasticidade condicional, ${ }^{15}$ (mais conhecido como modelo ARCH) foi introduzido por Engle (1982). Trata-se de um modelo não linear no que se refere a sua equação de variância, já que essa é uma função não linear de valores da série defasados no tempo. Esse modelo é adequado para representar as alterações de variância para séries temporais que exibem períodos de grande volatilidade alternados com períodos de relativa tranquilidade. Essa também é uma característica comumente apresentada por séries financeiras.

$\mathrm{O} \mathrm{ARCH}$ expressa a variância condicional do termo de erro como defasagem distribuída do quadrado dos valores da série passados. A variância condicional difere da não condicional na medida em que aquela está condicionada no modelo aos valores da série passados, ao passo que a variância não condicional é calculada a partir de todas as observações da amostra da série temporal, apresentando essa última um único valor. Por esse motivo a variância condicional é mais apropriada para estudar as mudanças temporais do padrão de volatilidade na série.

A variância condicional no modelo $\mathrm{ARCH}$ se comporta como um processo autorregressivo, de acordo com a seguinte especificação:

$$
\begin{aligned}
& X_{t}=\sqrt{h_{t}} \varepsilon_{t} \\
& h_{t}=\alpha_{0}+\alpha_{1} X_{t-1}^{2}+\ldots+\alpha_{p} X_{t-p}^{2}
\end{aligned}
$$

Onde,

$\mathrm{X}_{\mathrm{t}}=$ são os valores da série;

$\varepsilon_{\mathrm{t}}=$ é uma sequência de variáveis aleatórias independentes e iden-

15 A heterocedasticidade ocorre quando a variância do processo estocástico muda ao longo do tempo. É observada geralmente em séries econômico-financeiras. 
ticamente distribuídas com média zero e variância um (ruído branco); $\alpha_{0}>0, \alpha_{i} \geq 0, i>0=$ são parâmetros a serem estimados.

Se $\alpha_{i}=0, i>0$, o modelo é condicionalmente homocedástico.

A expressão (2) acima permite ver que o modelo ARCH captura agrupamentos de volatilidade devido ao fato de que a volatilidade $h_{t}$ é função quadrática crescente dos valores da série passados. Dessa forma, se a volatilidade no momento passado foi grande, a volatilidade no presente também tende a ser grande. Uma vantagem adicional do modelo ARCH é que ele permite capturar o excesso de curtose ${ }^{16}$ existente em séries econômicas, isso é, as caudas serão mais pesadas do que as da distribuição normal.

Por outro lado, uma desvantagem do modelo é que ele supõe que a variância condicional no instante $t$ depende dos quadrados de inovações passadas, ou seja, ela é afetada simetricamente por inovações positivas ou negativas. No entanto, sabe-se que a volatilidade reage de modo diferente a retornos positivos e negativos. Ademais, devido ao fato de termos retornos ao quadrado, alguns retornos grandes e isolados podem conduzir a superprevisões (MORETTIN; TOLOI, 2004). No presente trabalho, não consideramos modelos talvez mais apropriados à estimativa da volatilidade de séries financeiras, tais como modelos GARCH, TARCH e outras especificações. Mas como o propósito aqui não é tanto obter estimativas com elevada precisão da volatilidade ou fazer previsões, mas poder obter um perfil aproximado da evolução temporal da volatilidade, consideramos que o modelo ARCH contempla esse objetivo.

O procedimento de estimação do modelo $\mathrm{ARCH}$ para cada série baseia-se nas seguintes etapas:

1. Estima-se um modelo ARMA adequado à série original dos dados visando remover a correlação serial da mesma, se essa existir. Também é importante verificar se a série original apresenta heterocedasticidade condicional. ${ }^{17} \mathrm{~A}$ partir da análise da função de autocorrelação (fac) e da função de autocorrelação parcial (facp) $)^{18}$ identificamos o modelo ARIMA através de sua estrutura de parâmetros autorregressivos e de médias móveis. Em linhas gerais, os valores da fac significativos correspondem aos parâmetros significativos de médias móveis e os valores da facp significativos correspondem aos parâmetros significativos da parte

16 Curtose é uma medida que caracteriza o "achatamento" da curva da função de distribuição. O seu valor é dado por $\left\{\mathrm{S}_{\mathrm{i}=1, \mathrm{n}}\left(\mathrm{X}_{\mathrm{i}}-\mu\right)^{4} /\left[(\mathrm{n}-1) \mathrm{s}^{4}\right]\right\}$.

17 Para isso existem dois testes, o teste de Box-Pierce-Ljung para $X_{\mathrm{t}}^{2}$ e o teste de multiplicadores de Lagrange (ML) de Engle - ver Morettin (2004).

18 As funções de autocorrelação e autocorrelação parcial, assim como os demais testes para o modelo ARCH, são feitos através do software STATA 8.2 a partir dos comandos ac e pac, respectivamente. 
autorregressiva do modelo ARMA. Por exemplo, quando a série apresentar uma fac com os lags 1, 2 e 4 significativos teremos um modelo MA ( 124 ), ao passo que apresentando o primeiro lag significativo na facp teremos um modelo AR (1). ${ }^{19}$ A seleção do modelo também é feita verificando os critérios de informação de Schwartz (SIC) e de Akaike (AIC).

2. Aplicamos a modelagem $\mathrm{ARCH}$ aos resíduos do modelo ARMA. Para isso, estudamos a função de autocorrelação parcial (facp) dos quadrados dos resíduos do modelo ARMA. Os lags das autocorrelações significativas dessa função indicarão os parâmetros autorregressivos do modelo ARCH.

3. A seguir, estudamos as propriedades dos resíduos do modelo ARCH identificado, verificando a condição de normalidade, homocedasticidade e não correlação (fase de verificação e diagnóstico do modelo ajustado).

4. Por fim, predizemos a variância condicional (volatilidade) do modelo da série utilizada.

Antes de apresentarmos os resultados do modelo $\mathrm{ARCH}$ estimado, cabe ressaltar que para se extrair a volatilidade de séries econômicas ou financeiras as mesmas devem ser estacionárias ou devem ter sido transformadas para que sejam estacionárias. Desse modo, foi aplicado o teste ADF (Aumented Dickey-Fuller), com o intuito de testar a hipótese de não estacionariedade das séries da Conta Financeira. A hipótese nula desse teste de estacionariedade é que a série apresenta raiz unitária, o que indica que a série não será estacionária caso não se rejeite a hipótese nula e será estacionária quando rejeitarmos tal hipótese. Os resultados dos testes de estacionariedade encontram-se no anexo do trabalho. Como podemos observar na Tabela 6, todas as séries analisadas apresentaramse estacionárias em nível, sendo assim, I(0). Portanto, a dimensão usada para as séries da Conta Financeira foi a de variáveis em nível.

\subsubsection{Modelo ARCH: resultados}

Baseado na sequência para a construção do modelo ARCH anteriormente descrita, identificamos, estimamos e verificamos um modelo para cada uma das 50 séries da conta financeira do Balanço de Pagamentos, apontadas na seção 4.1, e então encontramos as volatilidades para todo o período escolhido, os meses dos anos 1995 a 2005.

A título de exemplo, iremos apresentar o resultado das estimações dos parâmetros do modelo ARCH para estimar a volatilidade da série In-

19 Para rodar o modelo ARIMA utilizamos o comando arima, no STATA 8.2. 
vestimento Direto Líquido, mostrado na Tabela 2, a seguir. Para cada série da conta financeira do Balanço de Pagamentos, foram estimados diversos modelos, seguindo-se as etapas descritas na seção anterior, sendo que escolheu-se a especificação que mais se ajustasse aos dados, de acordo com o critério de máxima verossimilhança.

Tabela 2 - Resultados do modelo ARCH para a série Investimento Direto Líquido

\begin{tabular}{c|c|c|c|c|c|c}
\hline & Coef. & Std. Err. & $Z$ & P $>z$ & \multicolumn{2}{|c}{ [95\% Conf. Interval] } \\
\hline cons & 668,7712 & 678,9667 & 0,98 & 0,325 & $-661,9791$ & 1999,5220 \\
\hline ARMA & & & & & & \\
\hline Ar & & & & & & \\
\hline L1 & 0,9671 & 0,0283 & 34,12 & 0,000 & 0,9115 & 1,0226 \\
\hline Ma & & & & & & \\
\hline L1 & $-0,7916$ & 0,0862 & $-9,18$ & 0,000 & $-0,9605$ & $-0,6226$ \\
\hline ARCH & & & & & & \\
\hline Arch & & & & & & \\
\hline L4 & 0,3805 & 0,1854 & 2,05 & 0,040 & 0,0171 & 0,7439 \\
\hline cons & 556815,5 & 103160,4 & 5,40 & 0,000 & 354624,9 & 759006,1 \\
\hline Numero
\end{tabular}

Número de observações $=123$. Log likelihood $=-1006,971$.

Wald chi2(2) $=1678,26$. Prob $>$ chi $2=0,000$.

Isso também pode ser apresentado através do seguinte sistema de equações:

$$
\begin{gathered}
y_{t}=668,7712+0,9671 y_{t-1}-0,7916 \varepsilon_{t-1}+\varepsilon_{t} \\
(678,9667)(0,0283) \quad(0,0862) \\
\operatorname{Var}\left(\varepsilon_{t}\right)=\sigma_{t}^{2}=556815,5+0,3805 \varepsilon_{t-4}^{2}
\end{gathered}
$$$$
(103160,4)(0,1854)
$$

Tendo em vista a grande quantidade de estimativas encontradas (12 por ano e para cada uma das 50 contas) iremos apresentar as médias anuais das volatilidades encontradas. Cabe salientar que os valores de volatilidade encontrados para cada série são valores bastante altos, uma vez que a volatilidade gerada a partir desse modelo é uma função quadrática crescente dos valores da série passados, conforme destacamos anteriormente. Os Gráficos 3, 4 e 5, que se seguem, apresentam as médias de volatilidades para o "segundo, terceiro e quarto nível de abertura" da Conta Financeira. ${ }^{20}$

20 Abstraímos os resultados para as contas do primeiro nível, uma vez que, como esperávamos, as contas mais voláteis encontradas foram os Investimentos em Carteira e Outros Investimentos. 
Através dos resultados encontrados é possível observar que algumas contas apresentam coeficientes de volatilidades muito altos, ao passo que outras contas apresentam coeficientes baixos (ver Gráficos 3, 4 e 5). Essa análise é, portanto, comparativa. Ademais, notamos que as subcontas são bastante flexíveis (voláteis) durante praticamente todo o período de análise. No "segundo nível" de abertura verificamos, através do Gráfico 3, que a série Outros Investimentos Estrangeiros e Investimentos Estrangeiros em Carteira foram as séries mais voláteis, com exceção do ano 2004, quando se observou uma elevação desse indicador na conta Investimento Brasileiros Diretos, que bateu recorde de movimento. ${ }^{21}$ Esse enorme volume de capital via Investimento Brasileiro Direto se deve ao aumento da Participação no Capital de importantes empresas brasileiras naquele ano. Como exemplo, verificou-se aumento de participações das empresas Ambev e Interbrew, resultante de troca de ativos.

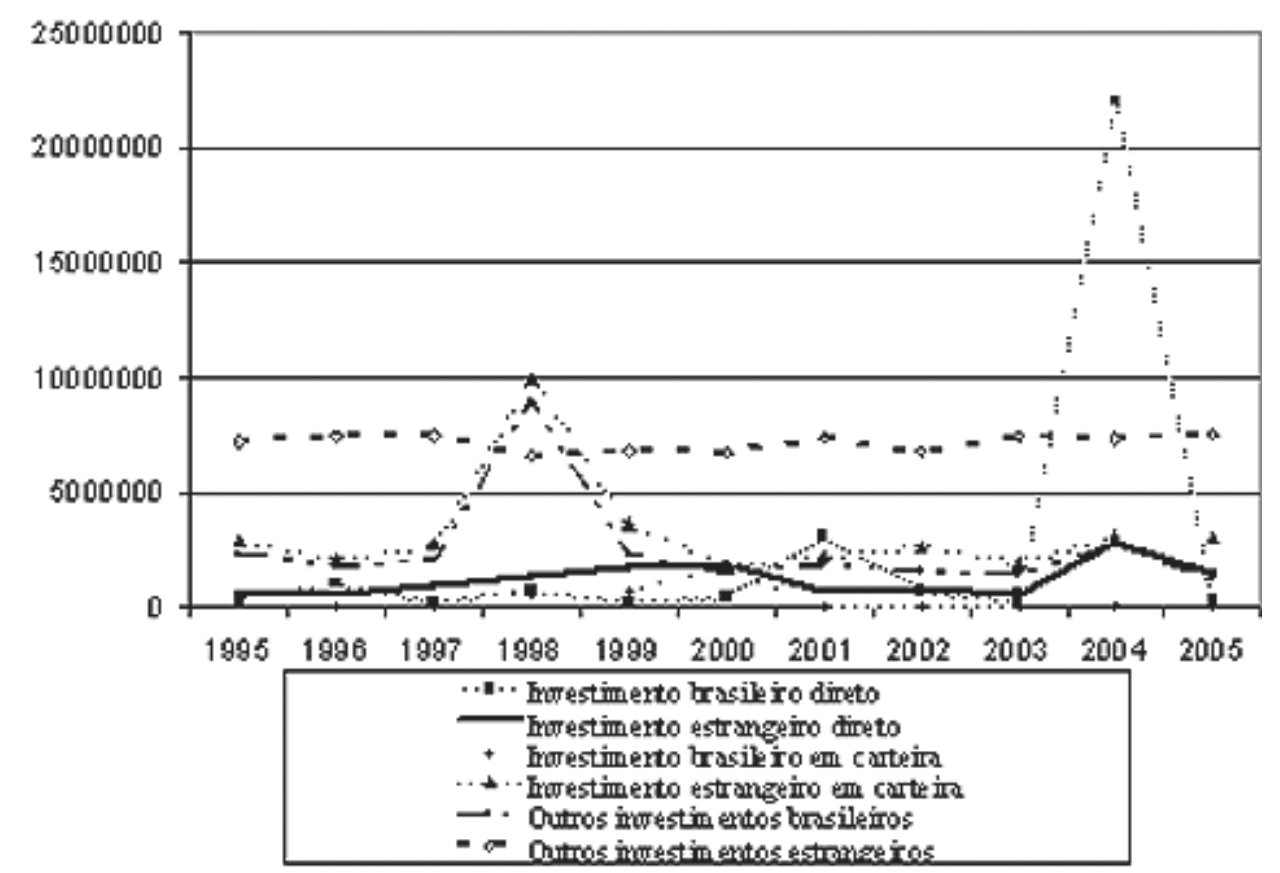

Gráfico 3 - Volatilidade Média para as séries do segundo nível de abertura Fonte: Elaboração própria.

No "terceiro nível" de abertura destacamos a série Empréstimos e Financiamentos, da subconta Outros Investimentos Estrangeiros, como a conta mais volátil (Gráfico 4). Por sua vez, no "quarto nível" de abertura o destaque ficou com a série Empréstimos à Autoridade Monetária, também

21 Esse recorde pode estar relacionado com a seguinte medida. A circular 3.268 de 16 de dezembro de 2004 do BCB alterou a legislação cambial, de forma a facilitar tanto o investimento brasileiro no exterior quanto o investimento estrangeiro no Brasil. Segundo o Banco, através desses instrumentos normativos, pessoas físicas ou jurídicas residentes, domiciliadas ou com sede no Brasil passaram a poder investir no exterior mediante conferência internacional de ações. 
dessa subconta. Portanto, conclui-se que foi essa série mais desagregada que puxou a volatilidade da subconta Outros Investimentos Estrangeiros.

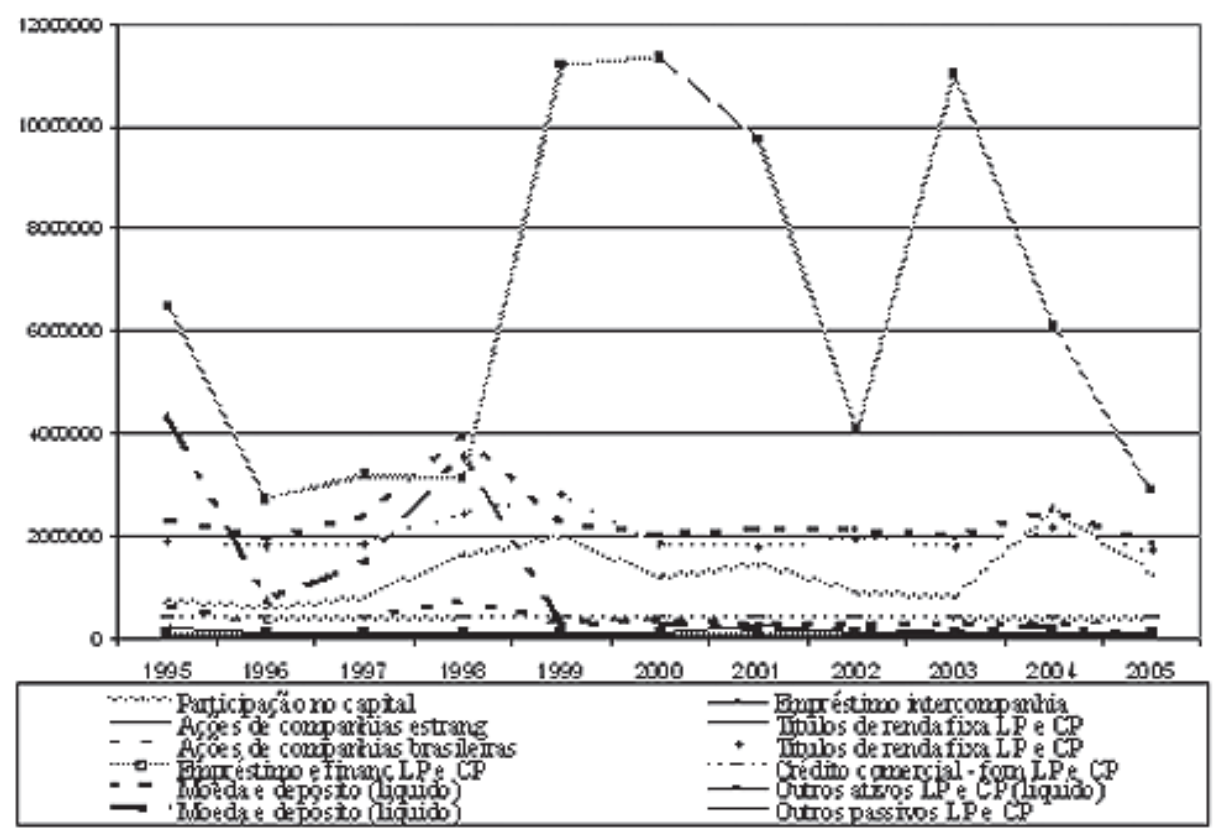

Gráfico 4 - Volatilidade Média para as séries do terceiro nível de abertura Fonte: Elaboração própria.

No entanto, devemos destacar que uma conta pode apresentar alta volatilidade, mas não representar peso significativo na Conta Financeira total. Para a análise de quais são as contas que mais influenciam a volatilidade do Balanço de Pagamentos toma-se, portanto, contas que apresentam maior parcela de participação na Conta Financeira.

Assim, com o intuito de verificar quais as contas que apresentaram maior volatilidade no período, conjugamos a média anual dessas volatilidades com a participação relativa de cada subconta em seu nível de hierarquia imediatamente superior. ${ }^{22}$ Para avaliar a volatilidade selecionamos, então, as médias das volatilidades e as participações relativas de cada nível de hierarquia para os dois períodos estabelecidos previamente.

Ao abrirmos as contas de Investimentos em Carteira e Outros Investimentos, a partir da Tabela 3, observamos maiores volatilidades e participação relativa para Investimentos Estrangeiros em Carteira e Outros Investimentos Estrangeiros, no primeiro período de análise, entre 1995 e 1998. Assim, as séries que apresentaram maiores valores de volatilidade são justamente aquelas que mais participam na Conta Financeira total, salientando a importância dos altos valores de volatilidade encontrados anteriormente.

22 Para o cálculo das participações relativas médias (para cada período de análise) foi utilizado o módulo de cada valor da Subconta Financeira, uma vez que o peso de cada uma delas na Conta Financeira não seria possível se a conta contribuísse negativamente na Conta Financeira total. 
Tabela 3 - Média de volatilidade e Participação Relativa Média para as séries do segundo nível de abertura

\begin{tabular}{|c|c|c|c|c|}
\hline Contas - Segundo Nível & $\begin{array}{c}\text { MV: } \\
1995 \text { a } 1998\end{array}$ & $\begin{array}{c}\text { PR: } \\
1995 \text { a } 1998\end{array}$ & $\begin{array}{c}\text { MV: } \\
1999 \text { a } 2005\end{array}$ & $\begin{array}{c}\text { PR: } \\
1999 \text { a } 2005\end{array}$ \\
\hline Investimento brasileiro direto & 591262 & 0,14 & 4288419 & 0,16 \\
\hline Investimento estrangeiro direto & 877710 & 0,86 & 1443688 & 0,84 \\
\hline Investimento brasileiro em carteira & 237412 & 0,07 & 440286 & 0,13 \\
\hline Investimento estrangeiro em carteira & 4420860 & 0,93 & 2582169 & 0,87 \\
\hline Outros investimentos brasileiros & 3800334 & 0,43 & 1890571 & 0,40 \\
\hline Outros investimentos estrangeiros & 7190838 & 0,57 & 7100352 & 0,60 \\
\hline
\end{tabular}

Fonte: Elaboração própria.

Esse resultado ainda mostra o fato de que o fluxo de recursos de estrangeiros é mais volátil, conforme já observamos previamente. Porém, esse resultado é ainda muito agregado, sendo que a abertura dessas contas nos esclarece em maior detalhe quais são os subfluxos que mais afetaram a volatilidade da Conta Financeira total. Assim, considerando o "terceiro nível" de abertura e desprezando-se os fluxos de Derivativos, chegamos ao resultado apresentado na Tabela 4.

Tabela 4 - Média de volatilidade e Participação Relativa Média para as séries do terceiro nível de abertura

\begin{tabular}{c|c|c|c|c}
\hline Contas - Terceiro Nível & MV: & PR: & MV: & PR: \\
\hline Participação no capital & 934071 & 0,89 & 1476883 & 0,80 \\
\hline Empréstimo intercompanhia & 84009 & 0,11 & 97310 & 0,20 \\
\hline Ações de companhias estrangeiras & 53992 & 0,21 & 59566 & 0,35 \\
\hline Títulos de renda fixa LP e CP & 57947 & 0,79 & 59420 & 0,65 \\
\hline Ações de companhias brasileiras & 508207 & 0,40 & 297236 & 0,29 \\
\hline Títulos de renda fixa LP e CP & 2006504 & 0,60 & 2036530 & 0,71 \\
\hline $\begin{array}{c}\text { Empréstimo e financiamento } \\
\text { LP e CP }\end{array}$ & 84146 & 0,12 & 79288 & 0,13 \\
\hline Moeda e depósito (líquido) & 2642643 & 0,68 & 2147294 & 0,80 \\
\hline Outros ativos LP e CP (líquido) & 126221 & 0,20 & 117655 & 0,07 \\
\hline $\begin{array}{c}\text { Crédito comercial - fornecedores } \\
\text { LP e CP }\end{array}$ & 400778 & 0,28 & 403140 & 0,27 \\
\hline $\begin{array}{c}\text { Empréstimos e financiamentos } \\
\text { LP e CP }\end{array}$ & 3879541 & 0,41 & 8665408 & 0,65 \\
\hline Moeda e depósito & 2539779 & 0,30 & 202670 & 0,08 \\
\hline Outros passivos LP e CP & 10760 & 0,01 & 613 & 0,00 \\
\hline
\end{tabular}

Fonte: Elaboração própria. 
Vemos que destacam-se como as contas que apresentaram maiores médias de volatilidade e altas participações relativas: Empréstimos e Financiamentos de Estrangeiros (pertencente a OIE), seguida por Moeda e Depósito de Brasileiros (pertencente a OIB), Moeda e depósitos de Estrangeiros (pertencente a OIE) e Títulos de Renda Fixa de Estrangeiros (pertencente a IEC). Através da Tabela 4, ainda verificamos que essas séries apresentam coeficientes de volatilidade de sete dígitos durante o primeiro período, enquanto a maior parte das contas do "terceiro nível" apresenta coeficientes de cinco e seis dígitos. Ademais, se observamos a volatilidade anual, é possível perceber o crescimento desse índice, especialmente em 1998, período de forte instabilidade.

Ou seja, por esses resultados já podemos concluir que os fluxos de Moeda e Depósitos influenciaram fortemente a volatilidade da Conta Financeira. Os relativos a brasileiros foram os que mais influenciaram, sendo que esses agregam os movimentos de depósitos de bancos brasileiros. Os relativos a estrangeiros se referem aos ingressos e saídas relacionados à antiga conta $\mathrm{CC} 5$, que contabilizou inclusive o ingresso de recursos de estrangeiros para aplicar indiretamente em títulos públicos no Brasil já que a aplicação direta em Títulos de Renda Fixa negociados no país tinha forte restrição para estrangeiros (SICSÚ, 2006).

No que se refere aos Investimentos em Carteira de Estrangeiros e aos Empréstimos e Financiamentos de Estrangeiros, é interessante abrir essas contas para detectar quais foram os principais subfluxos que as influenciaram, para termos uma maior ideia dos determinantes de suas volatilidades.

Tabela 5 - Média de volatilidade e Participação Relativa Média para as séries do quarto nível de abertura

\begin{tabular}{|c|c|c|c|c|}
\hline Contas - Quarto Nível & $\begin{array}{c}\text { MV: } \\
1995 \text { a } 1998\end{array}$ & $\begin{array}{c}\text { PR: } \\
1995 \text { a } 1998\end{array}$ & $\begin{array}{c}\text { MV: } \\
1999 \text { a } 2005\end{array}$ & $\begin{array}{c}\text { PR: } \\
1999 \text { a } 2005\end{array}$ \\
\hline Brazilian Depositary Receipts - BDR & 46805 & 0,14 & 53052 & 0,16 \\
\hline Demais & 5613 & 0,86 & 5529 & 0,84 \\
\hline Títulos de renda fixa LP & 345526 & 0,99 & 130700 & 0,93 \\
\hline Títulos de renda fixa CP & 1124 & 0,01 & 575 & 0,07 \\
\hline Negociadas no país & 721797 & 0,75 & 211136 & 0,62 \\
\hline $\begin{array}{l}\text { Negociadas no exterior } \\
\text { (Depositary Receipts) }\end{array}$ & 157773 & 0,25 & 258342 & 0,38 \\
\hline Negociadas no país LP e CP & 917445 & 0,16 & 252463 & 0,07 \\
\hline Negociadas no exterior LP e CP & 1642052 & 0,84 & 1800330 & 0,93 \\
\hline Empréstimo e financiamento LP & 28840 & 0,34 & 27627 & 0,67 \\
\hline Empréstimo e financiamento CP & 31810 & 0,66 & 26577 & 0,33 \\
\hline Outros ativos LP & 133123 & 0,02 & 9711942 & 0,26 \\
\hline
\end{tabular}




\begin{tabular}{c|c|c|c|c}
\hline Outros ativos CP & 250417 & 0,98 & 16313 & 0,74 \\
\hline Crédito comercial - fornecedores LP & 26025 & 0,22 & 20445 & 0,26 \\
\hline Crédito comercial - fornecedores CP & 429178 & 0,78 & 401111 & 0,74 \\
\hline Autoridade monetária & 3245753 & 0,08 & 5205216 & 0,55 \\
\hline Demais setores LP e CP & 1642360 & 0,92 & 1035627 & 0,45 \\
\hline Outros passivos LP & 2,8 & 0,03 & 2,8 & 0,50 \\
\hline Outros passivos CP & 27661 & 0,97 & 1529 & 0,50 \\
\hline
\end{tabular}

Fonte: Elaboração própria.

É possível perceber pela Tabela 5, referente ao "quarto nível" de abertura, que os fluxos que agregaram maior volatilidade foram os relativos a Empréstimos à Autoridade Monetária, seguidos pelos Financiamentos aos Demais Setores. No entanto, a primeira conta se apresentou muito volátil ao passo que não significativa na subconta de nível hierárquico superior. Sendo assim, a série Títulos Negociados no Exterior LP e CP foi bastante volátil e significativa na subconta Investimentos Estrangeiros em Carteira, explicando melhor a alta volatilidade dessa subconta, que tem caráter altamente especulativo. Outro destaque foi a série de Títulos Negociados no exterior LP e CP, da conta Outros Investimentos estrangeiros. Essa série foi bastante volátil e significativa na conta financeira.

Com relação ao segundo período, que vai de 1999 a 2005, verificamos que a alta volatilidade persiste, sendo que, em alguns casos (para algumas séries financeiras), ela até aumenta. A dinâmica dos fluxos segue fortemente influenciada por movimentos especulativos, seguindo a lógica da liquidez internacional. Ainda que os patamares de volatilidade sejam menores em relação ao primeiro período de análise, ocorrem movimentos importantes de volatilidade. Agora, os impactos da volatilidade dos fluxos de capitais se ajustam mais fortemente via taxa de câmbio e o movimento das taxas de juros passa a ser menor, como também é menor o seu patamar. Ademais, a Balança Comercial começa a melhorar, gerando-se, paulatinamente, resultados positivos em Transações Correntes. Do lado da Conta Financeira, seguindo a tendência da dinâmica dos fluxos direcionados aos países periféricos, observa-se uma queda da participação dos Investimentos em Carteira na mesma, uma baixa oferta de empréstimos bancários e uma maior participação dos Investimentos Diretos.

Após um período de forte instabilidade referente ao interregno 1999-2002 nota-se que, a partir de 2003, ocorre um retorno dos fluxos de Investimentos em Carteira (créditos) ${ }^{23}$ e mesmo de empréstimos bancários.

23 É preciso comentar que os resultados líquidos da conta Investimentos em Carteira são de baixa magnitude e por vezes negativos, tendo em vista o pagamento de dívidas vincendas ou mesmo a recompra de papéis que envolvem o pré-pagamento de dívidas. 
Esse interregno 2003-2005 é relativo a um período de expansão da liquidez internacional, fato também já salientado, observando-se que entre esses anos o resultado de Transações Correntes passa a ser fortemente favorável, ocorrendo uma melhora substantiva nas contas externas.

Ocorre, no entanto, que a vulnerabilidade das contas externas se mantém, tendo em vista o perfil dos capitais ingressantes e a lógica de movimento dos mesmos. $\mathrm{O}$ que queremos salientar é que permanece $\mathrm{O}$ alto peso dos fluxos de capitais flexíveis sobre o Balanço de Pagamentos brasileiro, sendo que esses agem condicionados pelo movimento da liquidez determinada nos mercados internacionais de capitais. Por serem altamente especulativos, a qualquer mudança de expectativas, continuam apresentando movimentos de reversão e, por isso, continuam apresentando forte volatilidade, também no segundo período analisado. Destacamos que as taxas de juros domésticas continuam influenciadas pela dinâmica dos fluxos de capitais. Esse comportamento pode ser percebido pela análise do movimento da Taxa Swap, que tem forte relação com o Risco País e com o câmbio e o da própria Taxa Selic que acaba também se ajustando aos impactos externos, ainda que com certa defasagem. Ou seja, a volatilidade desses fluxos gera efeitos macroeconômicos, mesmo quando não se apresenta uma crise mais profunda.

Analisando os coeficientes de volatilidade e a participação relativa para os dados do segundo período em análise, observa-se que obtivemos os mesmos resultados para as contas do primeiro nível: altos valores de volatilidade e participação relativa para as contas Investimentos em Carteira e Outros Investimentos.

No que tange às séries do "segundo nível", observou-se (Tabela 3) que a volatilidade é relativamente menor no segundo período, só que no ano de 2004 nota-se um forte crescimento da volatilidade desses fluxos, em especial para a conta Investimentos Brasileiros Diretos. Considerando as participações relativas, as contas Investimentos de Estrangeiros em Carteira e Outros Investimentos de Estrangeiros, podem ser ditas as mais voláteis durante todo esse segundo período analisado, sendo que a última conta citada tem um peso de volatilidade muito maior do que o das demais.

Abrindo as contas para o "terceiro nível" é possível comparar melhor os dois períodos (Tabela 4). Destacam-se duas diferenças importantes. A primeira é que a volatilidade da conta Empréstimos e Financiamentos se exacerba e se destaca muito das demais, sendo que a análise da evolução temporal da volatilidade nos mostra que os picos se apresentaram nos anos de 1999, 2000 e 2003. A segunda refere-se à conta Moeda e Depósitos de Estrangeiros, que passou a apresentar baixos valores de volatilidade e participação relativa, deixando de ser importante para a 
explicação da volatilidade da Conta Financeira. As duas outras contas que se destacaram no primeiro período em termos de volatilidade - Moeda e Depósitos de Brasileiros e Aplicações de Estrangeiros em Títulos de Renda Fixa - continuaram estando entre as mais voláteis nessa segunda fase, ainda que em menor grau. Destaque-se, no entanto, que a conta Moeda e Depósitos de Brasileiros continuou apresentando uma volatilidade importante, sendo que ela se destacou especialmente nos anos de 1999 e 2004, anos de instabilidade.

Tendo sido indicada a performance das contas relativas a Moeda e Depósitos, nos interessa entender melhor quais foram os sub-fluxos que mais influenciaram as volatilidades de Empréstimos e Financiamentos e Títulos de Renda Fixa. Para tal, consideramos o "quarto nível" de abertura da Conta Financeira, observando a Tabela 5. Juntando-se a questão da volatilidade com o peso do fluxo analisado sobre a Conta Financeira, observamos que os fluxos mais expressivos foram os relativos aos Empréstimos às Autoridades Monetárias e aos Investimentos de Estrangeiros em Títulos de Renda Fixa, Negociados no Exterior, com alta participação relativa, apesar de média de volatilidade menor em relação ao primeiro período.

A partir daí, corroboramos o apontamento das primeiras seções: de que as contas de Investimentos em Carteira e Outros Investimentos - principais definidoras da volatilidade da Conta Financeira - são dominadas por fluxos altamente flexíveis que apresentam altos níveis de volatilidade, mesmo neste segundo período, com destaque para o ano de 2004 quando não se apresentam choques cambiais. Assim, pode-se observar que as subcontas mais voláteis, mesmo quando abrimos as contas para o terceiro e quarto níveis de abertura, são justamente aquelas de maior caráter especulativo e viés de curto prazo.

\section{Considerações Finais}

Procuramos destacar neste trabalho a questão da vulnerabilidade do Balanço de Pagamentos brasileiro advinda da incorporação de fluxos financeiros altamente flexíveis, situação aprofundada pelo processo de abertura observado a partir dos anos 1990. O argumento defendido é o de que a abertura financeira e comercial, conjugada à primazia da política doméstica de combate à inflação, gerou efeitos perversos sobre o Balanço de Pagamentos nacional, que permanecem mesmo quando a liquidez internacional volta a ocorrer por um período mais longo - após 2003.

O que buscamos destacar é que o alto peso desses capitais flexíveis sobre a Conta Financeira leva a que sejamos continuamente impactados por importantes movimentos de volatilidade a qualquer mudança nas expectativas dos mercados financeiros internacionais. Ademais, a centra- 
lidade do combate à inflação magnificou essa dinâmica, quer pela manutenção dos juros em patamares altos, quer pelos impactos positivos sobre a inflação resultante da valorização da moeda nacional em momentos de liquidez. O que se observou foi que no primeiro período estudado, o nível alto dos juros se relacionou à funcionalidade da extremada atração de capitais nesses momentos de alta liquidez, para provocar a valorização do câmbio. Paralelamente, nos momentos de fuga de recursos, obviamente permaneceu a lógica de atração - naquele momento, para fechar as necessidades de financiamento do Balanço de Pagamentos. Nesse sentido, montou-se uma armadilha macroeconômica.

O que nosso trabalho buscou retratar é o fato de que, mesmo após a adoção do regime de câmbio flutuante a instabilidade continua. A volatilidade dos capitais se mantém, como demonstram os momentos de instabilidade do câmbio em 1999, 2001, 2002 e 2004, e isso foi observado através dos altos níveis de volatilidade dos fluxos componentes da Conta Financeira. O nosso destaque vai para o fato de que, mesmo quando as condições de liquidez melhoram (após 2003) não se desarma a armadilha da volatilidade e a queda dos juros domésticos continua atrelada a essa questão.

Entre 1999 e 2002, os altos patamares dos juros permanecem para controlar os impactos inflacionários resultantes das variações cambiais e para continuar atraindo capitais. Por outro lado, mesmo quando esses choques não mais se apresentam e o país entra em uma trajetória de valorização do câmbio (de 2003 em diante), a queda dos juros é lenta e fica na contínua dependência do que ocorre com a liquidez externa. Toda vez que ocorrem acontecimentos nos mercados financeiros internacionais que possam afetar as taxas de juros dos países centrais, apresenta-se um crescimento da volatilidade dos fluxos financeiros mais flexíveis do Balanço de Pagamentos - os relacionados à Moeda e Depósitos, Investimentos em Carteira e a empréstimos de curto prazo; que têm alto peso na Conta Financeira.

A taxa Selic responde a esse crescimento de volatilidade: ou aumentando seu patamar (em período de maior fuga de recursos) ou estancando seu ritmo de queda (em período de fuga menos intensa e de melhora de indicadores). Isso pôde ser percebido no início de 2004, por exemplo, quando as taxas de juros norte-americanas entraram numa trajetória de aumento.

Desse modo, subordina-se a política econômica e as metas de crescimento da economia às flutuações dos mercados de capitais mundializados, que podem passar abruptamente da euforia à depressão. Ou seja, mantêm-se os juros altos para continuar atraindo capitais, mesmo quando caem o Risco País e a inflação. De outro lado, está clara a possibilidade 
de reversão desse movimento, como indica a dinâmica recente de feast or famine. A contínua "necessidade" de atração de capitais voláteis e altamente flexíveis mantém o país dependente das expectativas especulativas e voláteis dos grandes capitais. Essa instabilidade, por sua vez, é tanto mais perversa, quanto maior for o peso dos capitais voláteis na Conta Financeira do Balanço de Pagamentos.

Por fim, cabe colocar que se a volatilidade dos fluxos financeiros é considerada um problema fundamental para a economia brasileira, especialmente em tempos de geração de reservas estrangeiras para cobrir os passivos externos dessa economia, então alguma proposta de política para reverter a fuga de capitais deve ser considerada, assim como a coordenação com outras políticas que desloquem a direção da acumulação para a esfera produtiva, gerando emprego e crescimento econômico.

\section{Referências}

AMADO, A. Preferência pela Liquidez: o novo contexto internacional inviabiliza a teoria? Revista de Economia Política, v. 24, n. 4 (96), 2004.

BANCO CENTRAL DO BRASIL. Notas Metodológicas do Balanço de Pagamentos. Notas técnicas do Banco Central do Brasil. n. 1, jun. p. 1-16, 2001.

CALVO L.; REINHART, C. Capital Inflows and Real Exchange Rate Appreciation in Latin America. IMF Staff Papers. 40 (1). Washington, D.C., 1993.

CALVO, G. A.; LEIDERMAN, L.; REINHART, C. M. Inflows of Capital to Developing Countries in the 1990s. Journal of Economic Perspectives, v. 10, n. 2, p. 123-139, Spring 1996.

CINTRA, M. A. M.; PRATES, D. M. Os fluxos de capitais para o Brasil nos anos 90. In: Antonio Correa de Lacerda. (Org.) Crise e Oportunidade: O Brasil e o Cenário internacional. São Paulo: Sobeet e Editora Lazuli, 2005.

CORRÊA, V. P. Fluxos de capitais, volatilidade e vulnerabilidade externa - uma análise do caso brasileiro pós-abertura financeira. Anais do XI Encontro Nacional de Economia Política, Vitória, 2006.

CORRÊA, V. P.; ALMEIDA FILHO, N. Engrenagem Macroeconômica: Inserção subordinada e custos de reversão da economia brasileira. Anais do XXXI Encontro Nacional de Economia. Salvador, 2003.

EDWARDS, S. Capital Flows, real Exchange rates and capital controls: some latin american experiences. NBER Working Papers, 6.000. 1998a.

. Interest rate volatility, investigation of the cases of Argentina, Chile and Mexico.

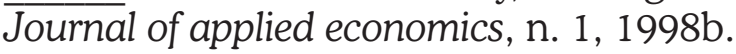

. Capital mobility and economic performance: are emerging countries different? NBER Working Papers, 8076, 2001.

FARHI, M. Metas de inflação e o medo de crescer. Política Econômica em Foco, n.4, maio/ out. Campinas: Unicamp, maio/out. 2004. 
FFRENCH-DAVIS, R. Financial crises and national policy issues: an overview. In: FfrenchDavis, R.; Griffith-Jones, S. (Orgs.) From capital surges to drought: seeking stability for emerging economies. New York, Palgrave Macmillan, 2003.

GARCIA, M. G. P.; OLIVARES, G. A. O Prêmio de Risco da Taxa de Câmbio no Brasil Durante o Plano Real. Departamento de Economia. PUC - Rio. Texto para discussão. n. 409. Rio de Janeiro, 1999.

GARCIA, M. G. P.; DIDIER, T. Taxa de juros, Risco cambial e Risco Brasil. Anais do XXIX Encontro Nacional de Economia. Salvador: ANPEC, 2001.

GONÇALVES, R. Globalização Financeira, liberalização cambial e vulnerabilidade externa da economia brasileira. In: BAUMAN, R. (Org.) O Brasil e a economia Global. Rio de Janeiro: Campus/SOBEET, 1996.

GRIFFITH JONES. The context for capital account liberalization; where goes the international financial system?. Institute of Development Studies - University of Sussex (mimeo), 2003.

GRIFFITH JONES; LEAPE. Capital Flows to low-income countries - Institute of Development Studies and London School of Economics (mimeo), 2002.

HERMANN, J. Financiamento de Longo Prazo: revisão do debate e propostas para o Brasil. In: SICSÚ, J.; OREIRO, J. L.; PAULA, L. F. (Orgs.) Agenda Brasil - Políticas econômicas para o crescimento com estabilidade de preços. Barueri, Manole/Fundação Konrad Adenauer, 2003.

IMF. Global financial stability report: market developments and issues. Washington, DC: IMF, April 2003.

LOPES-MEJÍA, A. Large Capital Flows: a survey of the causes, consequences and policy responses. IMF Working Paper, february. Washington, DC, 1998.

MIGUEL, P. P. Paridade de Juros, Fluxos de Capitais e eficiência do mercado de Câmbio no Brasil: evidência dos anos 90. Dissertação apresentada à FEA/USP, 2001.

MORETTIN, P. A.; TOLOI, C. M. C. Análise de séries temporais - São Paulo: Edgard Blucher, 2004.

PASTORE A.; PINOTTI. A capacidade de crescer e as políticas macroeconômicas. Estudos e Pesquisas, n. 18, INAE (Instituto Nacional de Altos Estudos), 2002.

PLIHON, D. A ascensão das finanças especulativas. Economia e Sociedade, v. 5, dez. 1995.

PRATES, D. M. Abertura financeira e vulnerabilidade externa: a economia brasileira na década de 90. Dissertação de mestrado. UNICAMP, 1997.

. As Assimetrias do Sistema Monetário e Financeiro Internacional. Revista de Economia Contemporânea, v. 9, n. 2, maio/ago. 2005.

PRATES, D. M.; FARHI, M. Economias emergentes e ciclos de liquidez. Anais do IV Colóquio de Economia da América Latina, FGV, São Paulo, 2004.

SICSÚ, J. A liberalização financeira brasileira no período 1988-2002. In: SICSÚ, J.; FERRARI FILHO, F. (Orgs.) Câmbio e controles de capitais, 2006. p. 222-245.

TAVARES, M. C. A Economia Política do Real. In: MERCADANTE, A. (Org) O Brasil pósReal - a política econômica em debate. Campinas: Ed. Unicamp, 1998.

TAVARES, M. C.; FIORI, L. Poder e dinheiro: Uma economia política da globalização. Petrópolis: Vozes, 1997. 
VIEIRA, F. V.; CARDOSO, C. A. Câmbio, Inflação e Juros na Transição do Regime Cambial Brasileiro: Uma Análise de Vetores Autorregressivos e Causalidade. Anais do VIII Encontro Nacional de Economia Política. Florianópolis, 2003.

\section{Anexo}

Tabela 6 - Teste de Raiz Unitária ADF - 1995: 01 a 2005: 03

\begin{tabular}{|c|c|c|c|c|c|c|c|c|}
\hline \multirow{2}{*}{ Variável } & \multirow{2}{*}{ Defasagem } & \multirow{2}{*}{ Constante } & \multirow{2}{*}{ Tendência } & \multirow{2}{*}{$\mathrm{ADF}$} & \multirow{2}{*}{$\mathrm{N}$} & \multicolumn{2}{|c|}{ Valor Crítico } & \multirow[b]{2}{*}{ t-probit } \\
\hline & & & & & & $1 \%$ & $5 \%$ & \\
\hline $\begin{array}{l}\text { Investimento } \\
\text { Direto }\end{array}$ & 0 & Sim & Não & -7.026 & $* 122$ & -3.503 & -2.889 & 0.0000 \\
\hline $\begin{array}{c}\text { Investimento } \\
\text { Brasileiro Direto }\end{array}$ & 0 & Sim & Não & -9.651 & $* 122$ & -3.503 & -2.889 & 0.0000 \\
\hline $\begin{array}{c}\text { Investimento } \\
\text { Estrangeiro Direto }\end{array}$ & 0 & Sim & Não & -7.098 & $* 122$ & -3.503 & -2.889 & 0.0000 \\
\hline $\begin{array}{c}\text { Participação } \\
\text { no capital }\end{array}$ & 0 & Sim & Não & -7.468 & $* 122$ & -3.503 & -2.889 & 0.0000 \\
\hline $\begin{array}{c}\text { Empréstimo } \\
\text { Intercompanhia }\end{array}$ & 0 & Sim & Não & -7.526 & $* 122$ & -3.503 & -2.889 & 0.0000 \\
\hline $\begin{array}{l}\text { Investimento } \\
\text { em Carteira }\end{array}$ & 0 & Sim & Não & -6.742 & $* 122$ & -3.503 & -2.889 & 0.0000 \\
\hline $\begin{array}{c}\text { Investimento } \\
\text { Brasileiro em } \\
\text { Carteira } \\
\end{array}$ & 0 & Sim & Não & -12.264 & *122 & -3.503 & -2.889 & 0.0000 \\
\hline $\begin{array}{c}\text { Ações de } \\
\text { Companhias } \\
\text { Estrangeiras }\end{array}$ & 0 & Sim & Sim & -14.923 & *122 & -3.503 & -2.889 & 0.0000 \\
\hline $\begin{array}{c}\text { Brazilian Depositary } \\
\text { Receipt }\end{array}$ & 0 & Sim & Não & -15.910 & $* 122$ & -3.503 & -2.889 & 0.0000 \\
\hline Demais & 0 & Sim & Não & -9.422 & $* 122$ & -3.503 & -2.889 & 0.0000 \\
\hline $\begin{array}{l}\text { Títulos de Renda } \\
\text { Fixa LP e CP }\end{array}$ & 0 & Sim & Não & -10.141 & $* 122$ & -3.503 & -2.889 & 0.0000 \\
\hline $\begin{array}{c}\text { Títulos de Renda } \\
\text { Fixa LP }\end{array}$ & 0 & Sim & Não & -10.106 & $* 122$ & -3.503 & -2.889 & 0.0000 \\
\hline $\begin{array}{c}\text { Títulos de Renda } \\
\text { Fixa CP } \\
\end{array}$ & 0 & Sim & Não & -1.070 & *122 & -3.503 & -2.889 & 0.0000 \\
\hline $\begin{array}{l}\text { Investimento } \\
\text { Estrangeiro } \\
\text { em Carteira }\end{array}$ & 0 & Sim & Não & -6.697 & $* 122$ & -3.503 & -2.889 & 0.0000 \\
\hline $\begin{array}{c}\text { Ações de } \\
\text { Companhias } \\
\text { Brasileiras }\end{array}$ & 0 & Sim & Não & -7.384 & $* 122$ & -3.503 & -2.889 & 0.0000 \\
\hline
\end{tabular}


(continuação)

\begin{tabular}{|c|c|c|c|c|c|c|c|c|}
\hline $\begin{array}{c}\text { Negociadas } \\
\text { no país }\end{array}$ & 0 & Sim & Não & -6.978 & *122 & -3.503 & -2.889 & 0.0000 \\
\hline $\begin{array}{c}\text { Negociadas } \\
\text { no exterior }\end{array}$ & 0 & Sim & Não & -8.487 & $* 122$ & -3.503 & -2.889 & 0.0000 \\
\hline $\begin{array}{l}\text { Títulos de Renda } \\
\text { Fixa LP e CP }\end{array}$ & 0 & Sim & Não & -7.542 & *122 & -3.503 & -2.889 & 0.0000 \\
\hline $\begin{array}{c}\text { Negociadas no país } \\
\text { LP e CP }\end{array}$ & 0 & Sim & Não & -6.986 & $* 122$ & -3.503 & -2.889 & 0.0000 \\
\hline $\begin{array}{c}\text { Títulos de Renda } \\
\text { Fixa LP }\end{array}$ & 0 & Sim & Não & -6.938 & $* 122$ & -3.503 & -2.889 & 0.0000 \\
\hline $\begin{array}{c}\text { Títulos de Renda } \\
\text { Fixa CP }\end{array}$ & 0 & Sim & Não & -8.565 & *122 & -3.503 & -2.889 & 0.0000 \\
\hline $\begin{array}{l}\text { Negociadas no } \\
\text { exterior LP e CP }\end{array}$ & 0 & Sim & Não & -7.713 & $* 122$ & -3.503 & -2.889 & 0.0000 \\
\hline Bônus de LP & 0 & Sim & Não & -10.604 & $* 122$ & -3.503 & -2.889 & 0.0000 \\
\hline $\begin{array}{c}\text { Notes e commercial } \\
\text { papers LP }\end{array}$ & 0 & Sim & Não & -7.643 & $* 122$ & -3.503 & -2.889 & 0.0000 \\
\hline $\begin{array}{c}\text { Títulos de Renda } \\
\text { Fixa CP }\end{array}$ & 0 & Sim & Não & -8.308 & $* 122$ & -3.503 & -2.889 & 0.0000 \\
\hline Derivativos & 0 & Sim & Não & -9.328 & ${ }^{*} 122$ & -3.503 & -2.889 & 0.0000 \\
\hline $\begin{array}{c}\text { Outros } \\
\text { Investimentos }\end{array}$ & 0 & Sim & Não & -9.608 & $* 122$ & -3.503 & -2.889 & 0.0000 \\
\hline $\begin{array}{c}\text { Outros } \\
\text { Investimentos } \\
\text { Brasileiros }\end{array}$ & 0 & Sim & Não & -15.821 & $* 122$ & -3.503 & -2.889 & 0.0000 \\
\hline $\begin{array}{c}\text { Empréstimo e } \\
\text { Financiamento } \\
\text { LP e CP }\end{array}$ & 0 & Sim & Não & -8.414 & $* 122$ & -3.503 & -2.889 & 0.0000 \\
\hline $\begin{array}{c}\text { Empréstimo e } \\
\text { Financiamento LP }\end{array}$ & 0 & Sim & Não & -8.449 & *122 & -3.503 & -2.889 & 0.0000 \\
\hline $\begin{array}{c}\text { Empréstimo e } \\
\text { Financiamento CP }\end{array}$ & 0 & Sim & Não & -9.663 & *122 & -3.503 & -2.889 & 0.0000 \\
\hline Moeda e Depósito & 0 & Sim & Não & -15.259 & *122 & -3.503 & -2.889 & 0.0000 \\
\hline $\begin{array}{l}\text { Outros Ativos } \\
\text { LP e CP }\end{array}$ & 0 & Sim & Não & -9.270 & $* 122$ & -3.503 & -2.889 & 0.0000 \\
\hline Outros Ativos LP & 0 & Sim & Não & -11.218 & $* 122$ & -3.503 & -2.889 & 0.0000 \\
\hline Outros Ativos CP & 0 & Sim & Não & -8.706 & *122 & -3.503 & -2.889 & 0.0000 \\
\hline $\begin{array}{c}\text { Outros } \\
\text { Investimentos } \\
\text { Estrangeiros }\end{array}$ & 0 & Sim & Não & -10.299 & $* 122$ & -3.503 & -2.889 & 0.0000 \\
\hline $\begin{array}{c}\text { Crédito comercial } \\
\text { e fornecedores } \\
\text { LP e CP }\end{array}$ & 0 & Sim & Não & -6.525 & *122 & -3.503 & -2.889 & 0.0000 \\
\hline
\end{tabular}

MUNHOZ, V. C. V.; CORRÊA, V. P. Volatilidade dos fluxos financeiros no Brasil: uma análise empírica... 
(continuação)

\begin{tabular}{|c|c|c|c|c|c|c|c|c|}
\hline $\begin{array}{l}\text { Crédito comercial } \\
\text { e fornecedores LP }\end{array}$ & 0 & Sim & Não & -2.373 & *122 & -3.503 & -2.889 & 0.0000 \\
\hline $\begin{array}{l}\text { Crédito comercial } \\
\text { e fornecedores CP }\end{array}$ & 0 & Sim & Não & -6.600 & *122 & -3.503 & -2.889 & 0.0000 \\
\hline $\begin{array}{c}\text { Empréstimos } \\
\text { e Financiamento } \\
\text { LP e CP }\end{array}$ & 0 & Sim & Não & -11.092 & *122 & -3.503 & -2.889 & 0.0000 \\
\hline $\begin{array}{l}\text { Autoridade } \\
\text { Monetária }\end{array}$ & 0 & Sim & Não & -10.973 & $* 122$ & -3.503 & -2.889 & 0.0000 \\
\hline $\begin{array}{c}\text { Operações } \\
\text { de regularização }\end{array}$ & 0 & Sim & Não & -10.994 & *122 & -3.503 & -2.889 & 0.0000 \\
\hline $\begin{array}{c}\text { Outros } \\
\text { Empréstimos LP }\end{array}$ & 0 & Sim & Não & -10.274 & *122 & -3.503 & -2.889 & 0.0000 \\
\hline $\begin{array}{c}\text { Demais setores } \\
\text { LP e CP }\end{array}$ & 0 & Sim & Não & -7.323 & *122 & -3.503 & -2.889 & 0.0000 \\
\hline $\begin{array}{l}\text { Empréstimos e } \\
\text { Financiamentos } \\
\text { demais setores }\end{array}$ & 0 & Sim & Não & -5.949 & *122 & -3.503 & -2.889 & 0.0000 \\
\hline $\begin{array}{c}\text { Empréstimos e } \\
\text { Financiamentos } \\
\text { demais setores CP }\end{array}$ & 0 & Sim & Não & -9.195 & *122 & -3.503 & -2.889 & 0.0000 \\
\hline Moeda e Depósito & 0 & Sim & Não & -8.799 & *122 & -3.503 & -2.889 & 0.0000 \\
\hline $\begin{array}{c}\text { Outros Passivos } \\
\text { LP e CP }\end{array}$ & 0 & Sim & Não & -14.361 & *122 & -3.503 & -2.889 & 0.0000 \\
\hline Outros Passivos LP & 0 & Sim & Não & -10.801 & $* 122$ & -3.503 & -2.889 & 0.0000 \\
\hline Outros Passivos CP & 0 & Sim & Não & -14.350 & *122 & -3.503 & -2.889 & 0.0000 \\
\hline
\end{tabular}

* indica estacionária a nível de 1\% de significância

** indica estacionária a nível de 5\% de significância

$\mathrm{D}=$ indica primeira diferença

$\mathrm{N}$ = número de observações

Fonte: Elaboração própria. Os testes de estacionariedade foram feitos utilizando o eviews 5.0, primeiramente verificando os impactos da constante para posteriormente verificar a hipótese nula.

Recebido em: 21/11/2008.

Aceito em: 04/12/2008. 